\title{
シラスバルーンを用いた陶磁器素地の軽量化
}

\author{
奥谷英司 · 西川 崇* · 田中寿郎* · 宮谷和雄* \\ 愛媛大学大学院理工学研究科, 790-8577 松山市文京町 3 番 \\ *愛媛大学工学部機能材料工学科, $790-8577$ 松山市文京町 3 番
}

\section{Preparation of Lightweight Porcelain Body by Mixing Shirasu-Balloon}

Eiji OKUTANI, Takashi NISHIKAWA, ${ }^{*}$ Toshiro TANAKA* and Kazuo MIYATANI*

Graduate School of Science and Engineering, Ehime University, 3, Bunkyo-cho, Matsuyama-shi 790-8577

*Department of Materials Science and Engineering, Faculty of Engineering, Ehime University, 3, Bunkyo-cho, Matsuyama-shi $790-8577$

\begin{abstract}
Lightweight porcelain has been developed by forming closed pores in the porcelain body through the use of hollow micro-spheres made from volcanic ash. These micro-spheres are called Shirasu-balloon. A green for lightweight porcelain was prepared by mixing the Shirasu-balloon with the green by hand. Experimental specimens were obtained by pressing the green, and drying and firing it at temperatures from 1160 to $1400^{\circ} \mathrm{C}$ for $2 \mathrm{~h}$ in air. Bulk density, liner shrinkage, and flexural strength were measured, and the morphology and structure of the Shirasu-balloon in the porcelain bodies were observed using SEM. When the Shirasu-balloon was mixed with green of less than 10 mass \%, the bulk density was reduced from 2.38 to $1.77\left(\times 10^{3} \mathrm{~kg}\right.$. $\mathrm{m}^{-3}$ ) along the ideal value. The Shirasu-balloon was deformed and was shrunk over $13 \%$ by the addition of the Shirasu-balloon at more than 20 mass \%. The density reduction did not progress ideally beyond this point and approached the saturation value. When the mixing ratio was less than 10 mass $\%$, the reduction of the flexural strength of the lightweight porcelain was slightly suppressed. This might be explained by the residual stress formed in the porcelain body.

[Received June 20, 2001; Accepted April 18, 2002]
\end{abstract}

Key-words : Lightweight porcelain, Shirasu-balloon, SEM, Bulk density, Liner shrinkage, Flexural strength

\section{1. 緒 言}

シラスバルーンは，日本各地に分布する火山ガラス質堆積物 （シラス）を原料として，急速加熱発泡にて作製されたガラス 質の微小中空球体である. 中空球体の低い密度と高い断熱性を 生かして, フィラーとして, 紙粘土, 建築部材, 断熱材などに 広く利用されている1),2)。また，このシラスバルーンを陶磁器 素地に混合し, 気孔を陶磁器中に形成して軽量化する試みもな されており3), 閉気孔率20\%程度の軽量陶磁器が得られてい る. 更に高密度に閉気孔を導入し素地を軽量化できれば，その 応用範囲は大きく広がるものと期待されるが， $1200^{\circ} \mathrm{C}$ 以上の 高温焼成を行う陶磁器素地に $30 \%$ 以上の割合で閉気孔を導入 した報告は今のところ見当たらないようである。高温焼成を必 要とする陶磁器素地に高密度にシラスバルーンを混合して，さ らなる軽量化を達成するためには，焼成過程におけるシラスバ ルーンの挙動を焼成温度及び，その混合率と関連して明らかに し，適切な条件を見いだす必要があると考えられる。また，セ ラミックスは, 通常, 内部に気孔が存在すると急激に強度が低 下するが，焼成体内部に残留応力を適切に分布させることがで きれば，気孔の形成に伴う強度低下を応力強化機構によって緩 和することも可能と考えられる4) 6).

そこで, 本研究では, 陶磁器素地中にシラスバルーンを段階
的に混合した試料の焼成過程において，シラスバルーンによる 閉気孔の形成を詳細に検討した。更に，閉気孔が形成された場 合の陶磁器素地の強度についても調べた.

\section{2. 実 験}

本研究では愛媛県砥部町で生産されている陶磁器坏土と三機 化工建設製シラスバルーン AS02 を使用した．表 1 と表 2 に本 研究で使用した坏土とシラスバルーンの化学組成及び粒度分布 をそれぞれ示す．市販のシラスバルーン粒子は中空をなしてい ないものや粗粒を含むので, 水道水を用いて水に浮く中空バ ルーン粒子のみを選別し，更に超音波ふるいを用いて75 $\mu \mathrm{m}$ 以 下の粒度を持つもののみを使用した. また，バルーン粒子の肉 厚を厚くし殼を強化する目的で，シラスバルーン粒子同士の融

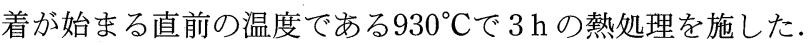
シラスバルーンのかさ密度 $\rho_{0}$ は蒸留水を用いたアルキメデス 法により測定した.

シラスバルーン混合素地は陶磁器坏土の乾燥質量に対してシ ラスバルーンを外割で $5,10,20$ mass \%及び 30 mass \% 混合 し，更に蒸留水をそれぞれ $20,25,30$ mass\%及び 35 mass\%加 え $20 \mathrm{~min}$ 手練することで作製した. 実験に用いた試料は，こ の混合素地をステンレス製のダイスを用い， $2 \mathrm{MPa}$ のプレス

Table 1. Chemical Composition of Green Body and Shirasu-Balloon

\begin{tabular}{lcccccccccc}
\hline \multirow{2}{*}{ Sample name } & \multicolumn{10}{c}{ Composition/mass\% } \\
\cline { 2 - 9 } & $\mathrm{SiO}_{2}$ & $\mathrm{Al}_{2} \mathrm{O}_{3}$ & $\mathrm{Fe}_{2} \mathrm{O}_{3}$ & $\mathrm{MgO}$ & $\mathrm{CaO}$ & $\mathrm{Na}_{2} \mathrm{O}$ & $\mathrm{K}_{2} \mathrm{O}$ & $\mathrm{TiO}_{2}$ & $\mathrm{Ig}$. Loss \\
\hline \multirow{2}{*}{ Green body } & 70.9 & 17.9 & 0.44 & 0.14 & 0.16 & 0.48 & 2.52 & 0.17 & 4.78 \\
Shirasu-balloon & $72-76$ & $12-14$ & $1.5-2.5$ & $0.3-1.0$ & $0.5-2.0$ & $2.0-3.0$ & $2.0-3.0$ & - & $0.1-1.0$ \\
\hline
\end{tabular}


Table 2. Particle Size Distribution of Green Body and Shirasu-Balloon

\begin{tabular}{|c|c|c|c|c|c|c|}
\hline \multirow{2}{*}{ Sample } & \multicolumn{6}{|c|}{ Particle size $/ \mu \mathrm{m}$} \\
\hline & $0-4.4$ & $4.4-8.8$ & $8.8 \cdot 13.2$ & $13.2 \cdot 17.6$ & $17.6-22.0$ & $22.0-26.4$ \\
\hline $\begin{array}{l}\text { Green body } \\
\text { (mass\%) }\end{array}$ & 29.1 & 23.6 & 9.98 & 9.53 & 7.57 & 5.22 \\
\hline \multirow{2}{*}{ Sample } & \multicolumn{6}{|c|}{ Particle size / $\mu \mathrm{m}$} \\
\hline & 0.45 & $45-75$ & $75-106$ & $106-150$ & $150-212$ & $212^{-}$ \\
\hline $\begin{array}{l}\text { Shirasu-balloon } \\
(\text { mass } \%)\end{array}$ & $30-42$ & $17-33$ & $17-22$ & $11-22$ & $6-8$ & 0 \\
\hline
\end{tabular}
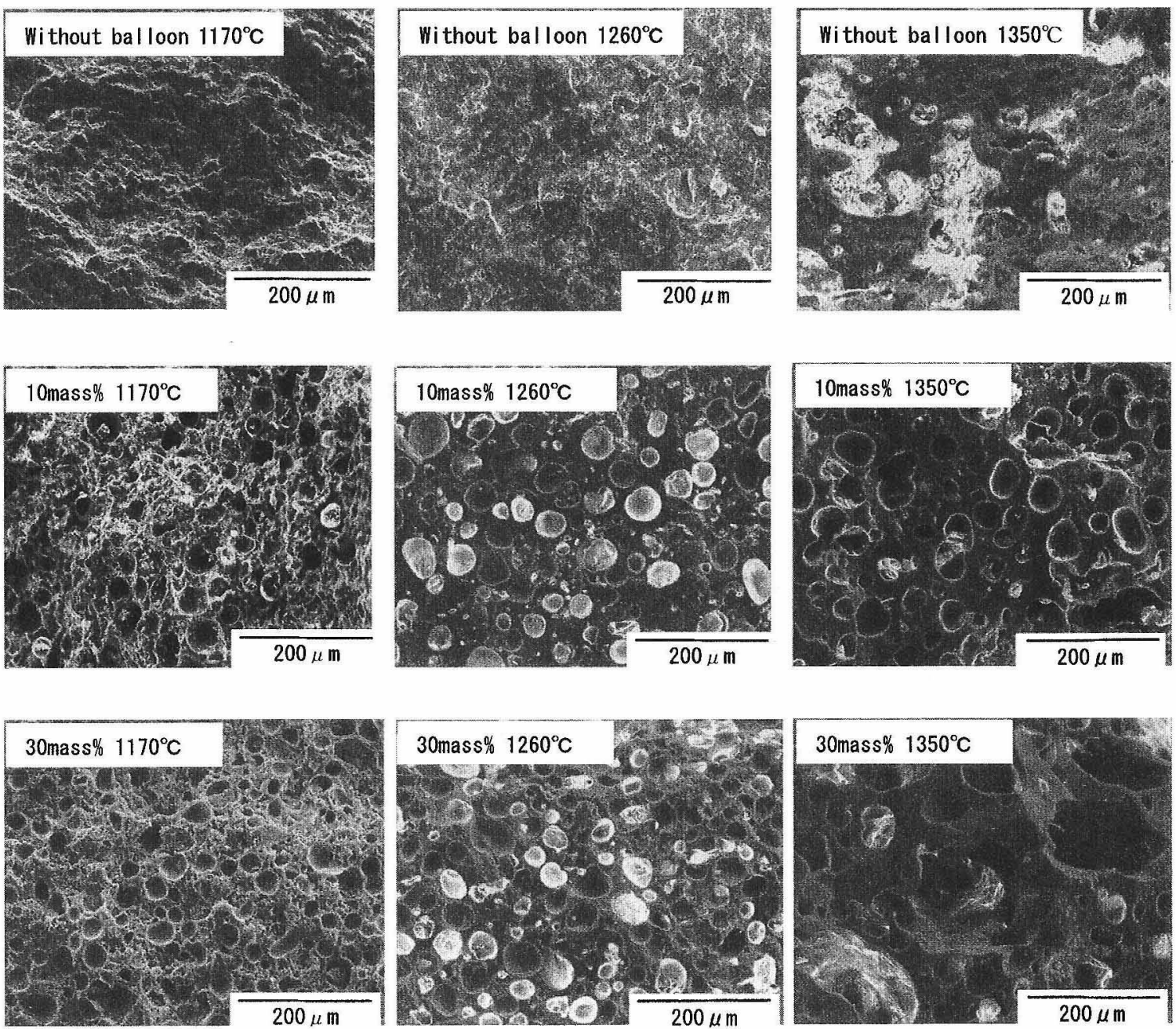

Fig. 1. SEM Photographs of fracture surface of Shirasu-balloon mixed porcelain bodies fired at various temperatures.

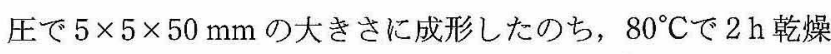
し， $1170 \sim 1400^{\circ} \mathrm{C}$ で $2 \mathrm{~h}$ 大気中焼成を行い作製した，実験に 用いた烧成体のかさ密度 $D_{\mathrm{B}}$ は蒸留水を媒体としたアルキメデ ス法により測定した。焼成線収縮率 $S$ は, 焼成前後の試料の 長さをノギスを用いて測定し計算した。試料の曲げ強度 $\sigma_{\mathrm{B}}$ は, JIS R1601に基づいて, スパン距離 $30 \mathrm{~mm}$, クロスヘッ ド速度 $0.5 \mathrm{~mm} / \mathrm{min}$ の条件で 4 点曲げ法により測定した。測定 值は 3 本の試料を測定し平均值を用いた．試料の断面は走查 型電子顕微鏡（SEM）を用いて観察した。試料中の石英の面
間隔は，X 線回折法（XRD）を用いて解析したが，測定は 3 回繰り返し，その平均值を採用した.

\section{1 混合素地の断面構造}

\section{3. 実験結果と考察}

焼成体の断面について SEM 観察を行った。図 1 には, 陶磁 器素地及びシラスバルーンを，10 mass\%, 30 mass\%混合した 混合素地について，それぞれ $1170^{\circ} \mathrm{C}, 1260^{\circ} \mathrm{C}$ 及び $1350^{\circ} \mathrm{C}$ 各 温度で焼成した試料の破断面を等倍で観察した SEM 写真を示 
す.

陶磁器素地の場合, $1170^{\circ} \mathrm{C} て ゙$ 焼成したものの破断面は, 凹 凸が多く, 粒子間に多くの気孔が観察され, 緻密化が不完全で あった. $1260^{\circ} \mathrm{C} て ゙$ 燒成したものの破断面は格段に滑らかにな り, 気孔も微小でほとんど観察できない。より高温の $1350^{\circ} \mathrm{C}$ 焼成では， $200 \mu \mathrm{m}$ にも及ぶ不定形の空隙が新たに現れた。こ れは, 素地中の閉気孔内のガスが膨張し素地を押し広げた結果 と考えられる.

一方, シラスバルーン混合素地の場合には, $1170^{\circ} \mathrm{C}$ 焼成で は混合率に依存せず球形の閉気孔が観察された. $1260^{\circ} \mathrm{C}$ 焼 成では, 混合率 10 mass\%の場合には球形に近い閉気孔が形成 されているが，30 mass\%では歪んだ形状の閉気孔が多く観察 された. 更に, $1350^{\circ} \mathrm{C}$ 高温焼成ではいずれの混合率の場合 も, 気孔が拡大し数が減少していた。 これは, シラスバルーン により形成された閉気孔と陶磁器素地中に形成された不定形の 気孔とが結合した結果と考えられる。

\section{2 混合素地のかさ密度及び収縮}

陶磁器素地及び, シラスバルーンを混合した焼成体のかさ密 度と焼成温度との関係を図 2 に示す. 図から分るように陶磁器 素地は, $1260^{\circ} \mathrm{C}$ 付近でかさ密度が最大になった。この結果を 図 1 の SEM 写真と合わせて考えると, 最大值を示す温度より 低温側では，素地中に気孔が残留し緻密化が不十分であったも のと考えられる. 一方, 上記温度より高温側では, 素地中の緻 密化に続いて閉気孔周囲のマトリックスの粘度低下が起こり, 閉気孔が膨張したために, かさ密度が低下したものと考光られ る. 次に, 陶磁器素地にシラスバルーンを混合していくと, シ ラスバルーンの混合率の増加に伴ってかさ密度が減少した。い ずれの混合率でもかさ密度が最大になる焼成温度は1260～ $1280^{\circ} \mathrm{C}$ 付近であり, 陶磁器素地のそれと大差がなかった。こ の結果は, 素地とシラスバルーンの化学組成が近く, 恐らくは その焼結温度も同程度であったためと考えられる。

$1260^{\circ} \mathrm{C}$ で焼成した混合素地の焼成線収縮率（以下収縮率と する）とシラスバルーンの混合率との関係を図 3 に示す. 陶磁

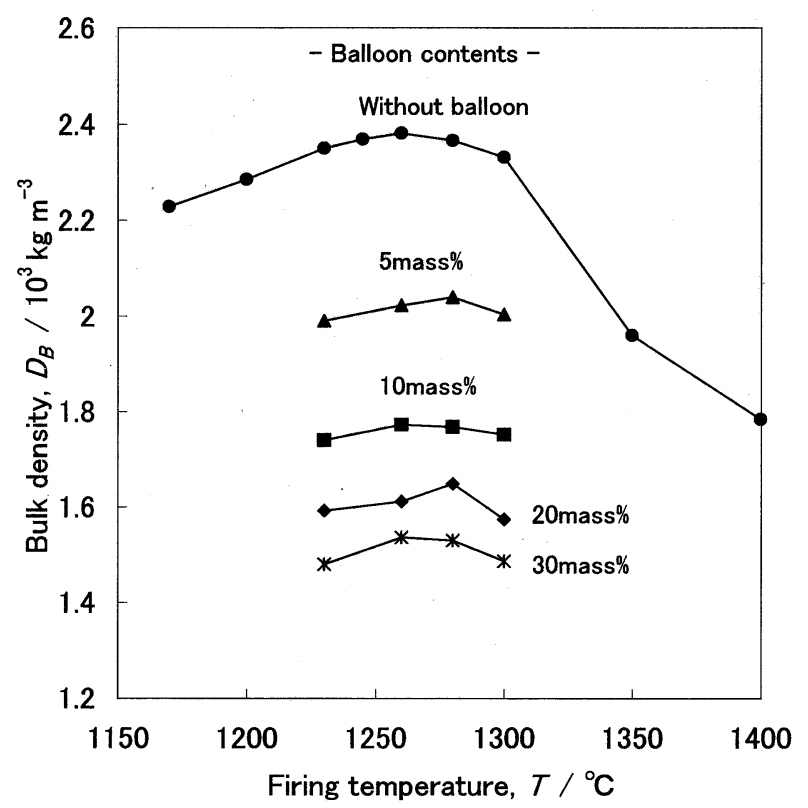

Fig. 2. Bulk density of Shirasu-balloon mixed porcelains, $D_{\mathrm{B}}$ vs. firing temperature, $T$ for the various mixing ratio of Shirasu-balloon.
器素地の収縮率は約 $9 \%$ であり, 混合率が 10 mass\%をではほ ぼ同じ収縮率を示している，更に混合率を増加させると急激に 収縮率が増加し，20 mass\%では約13\%, 30 mass\%では約15\% となった. 比較のために, 同図にはシラスバルーンを粉砕し,

気孔を完全につぶしたものを混合した場合について示した. 気 孔をつぶした場合には, 収縮率は陶磁器素地とほぼ同程度で あった. したがって, シラスバルーンを混合した場合に観察さ れた収縮率の増加は, シラスバルーンによって焼成体中に形成 された気孔の体積減少に起因することが示唆される.

$1260^{\circ} \mathrm{C}$ で焼成した試料のかさ密度とシラスバルーンの混合 率との関係を図 4 に示す。混合率 10 mass\%までは試料のかさ 密度は大幅に低下したが, それ以上の混合率ではかさ密度の低 下は緩やかになっている．したがって，シラスバルーンの混合 率を増加しても軽量化への寄与はしだいに小さくなることが分 る. そこで, 以下に素地のかさ密度とシラスバルーンの混合率 及び焼成収縮率の関係について考察する.

シラスバルーンの焼成前の内径を $d_{0}$, 焼成後の内径を $d$ と おくと, シラスバルーンの焼成収縮率 $t$ は $t=\left(d_{0}-d\right) / d_{0}$ とな る. かさ密度はシラスバルーンによる閉気孔によってのみ影響 されると仮定すると, 素地のかさ密度 $D_{\mathrm{Cal}}(t)$ は,

$$
D_{\text {Cal }}(t)=\frac{1+x / 100}{1 / D_{0}+\left(x /\left(100 \cdot \rho_{0}\right)\right) \cdot(1-t)^{3}}
$$

と表される．ここで， $D_{0}$ は $1260^{\circ} \mathrm{C}$ 焼成時の素地のかさ密度で あり，計算には実測值 $D_{0}=2.38 \times 10^{3} \mathrm{~kg} \cdot \mathrm{m}^{-3}$ を用いた。 ま た， $x$ はバルーンの混合率であり,$\rho_{0}=0.42 \times 10^{3} \mathrm{~kg} \cdot \mathrm{m}^{-3}$ は焼 成前のシラスバルーンのかさ密度である.

(1) 式によるかさ密度の計算值 $D_{\mathrm{Cal}}(t)$ を, $t$ をパラメーター として図 4 に併せて示した. $t=0$ はシラスバルーンの焼成収 縮がない場合を，また $t=0.09$ はシラスバルーンの収縮率が素 地のそれと等しいことを意味する. 実験值を計算值と比較する と, 混合率 10 mass\%までは, $t=0.09$ による計算值に近いが, $20 \mathrm{mass} \%$ 以上の混合率では, $t=0.09$ による計算值よりも大き

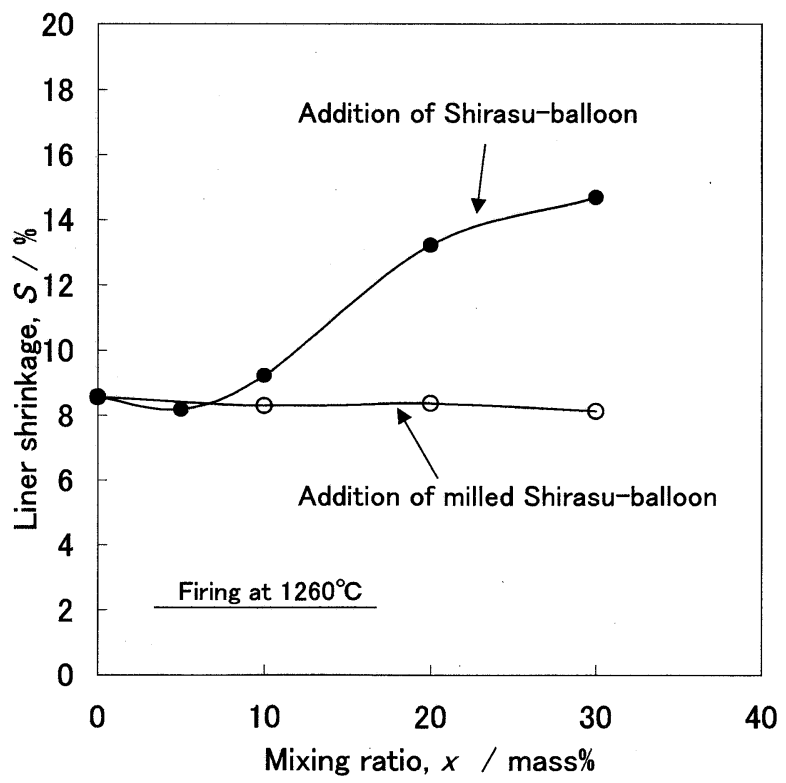

Fig. 3. Liner shrinkage, $S$ of the Shirasu-balloon mixed porcelains fired at $1260^{\circ} \mathrm{C}$ vs. the Mixing ratio, $x$. The solid circles and open circles denote the shrinkage of the porcelains mixed with hollow Shirasu-balloon and milled non-hollow Shirasu-balloon, respectively. 


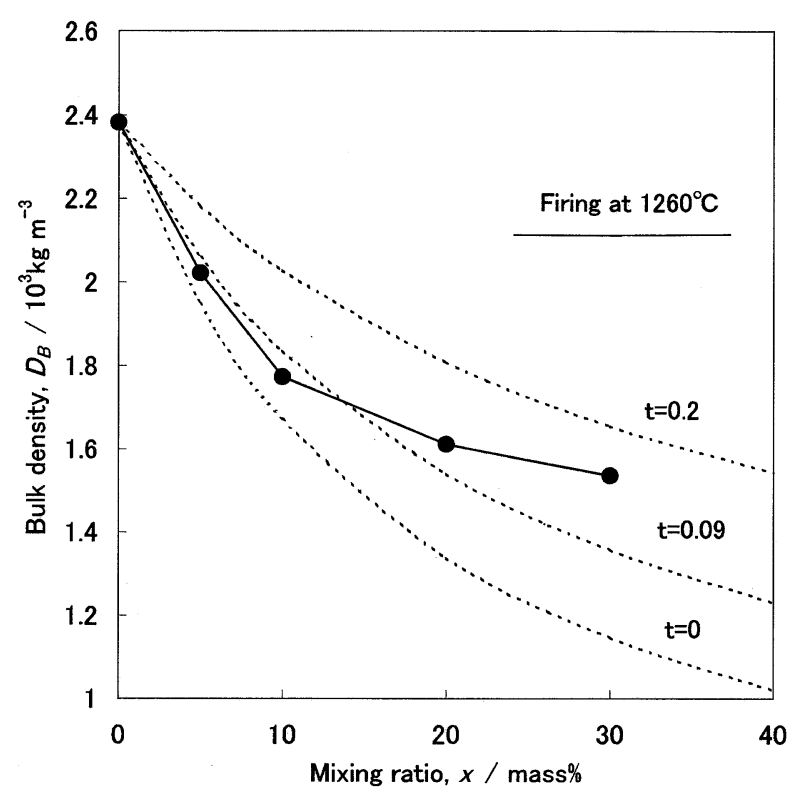

Fig. 4. Bulk density, $D_{\mathrm{B}}$ of the Shirasu-balloon mixed porcelains fired at $1260^{\circ} \mathrm{C}$ vs. the Mixing ratio, $x$. The dotted lines show the calculated values $D_{\text {Cal }}(t)$ using shrinkage of the Shirasu-balloon, $t$ as a parameter, which discusses in Section 3.2.

くなっており，シラスバルーンの収縮がより大きくなったこと が示唆される。

そこで，シラスバルーンの気孔径を図 1 の SEM 写真（1260 ${ }^{\circ} \mathrm{C}$ 焼成時, 混合率 10, 30 mass\%）の $400 \mu \mathrm{m} \times 400 \mu \mathrm{m}$ の範囲 から実測して求めると，それぞれ平均で， $32 \mu \mathrm{m}$ (10 mass\%), $27 \mu \mathrm{m} \quad(30$ mass $\%)$ であった。 な抢気孔径の測定は気孔がだ 円の場合，その長軸及び短軸の平均值を採用した.このように 同じ焼成温度でも混合率が増加するとシラスバルーンの収縮 は，より大きくなる傾向をもつことが分った。

この原因については以下のように考えられる．素地中のシラ スバルーンの体積率を混合率 10 mass\%から計算すると，49 vol\%となる．この值は，シラスバルーンが等大球で単純立方 構造であるときの体積率である $52 \mathrm{vol} \%$ に近い. したがって混 合率が 10 mass\%を超えると，シラスバルーンはお互いに接触 することが多く，そのためにシラスバルーン同士の結合や，外 表面との連結が起こり，混合素地の大きな収縮へとつながった のではないかと考えられる.

\section{3 混合素地の曲げ強度}

$1260^{\circ} \mathrm{C}$ で焼成した試料の曲げ強度とシラスバルーンの混合 率の関係を図 5 に示す。陶磁器素地の曲げ強度 $\sigma_{0}$ は約 $75 \mathrm{MPa}$ であったが，シラスバルーンの混合に伴って曲げ強度 $\sigma_{\mathrm{B}}$ は低 下し，混合率 10 mass\%のとき約 $50 \mathrm{MPa}$ ，混合率が 20 mass\% 及び30 mass\%ではいずれも約 $35 \mathrm{MPa}$ となった.

シラスバルーンの素地への混合による軽量化と強度の低下の 関係を見るために，バルーンを混合しないときの焼成体（焼成 温度 $\left.1260^{\circ} \mathrm{C}\right)$ のかさ密度及び曲げ強度を基準として，それぞ れに計算した相対かさ密度 $D_{\mathrm{B}} / D_{0}$ と相対曲げ強度 $\sigma_{\mathrm{B}} / \sigma_{0}$ の関 係を図 6 に示した。 また，気孔率を $1-D_{\mathrm{B}} / D_{0}$ とし， $b$ を定数 とすると，多孔質セラミックスの曲げ強度を示す実験式として

$$
\frac{\sigma}{\sigma_{0}}=\exp \left(b\left(1-\frac{D}{D_{0}}\right)\right)
$$

が多く用いられている8 ${ }^{8), 9)} . b$ については1.4 11の值が報告さ れている. 本研究の結果から $b$ 值を求めると 1.8 程度であっ

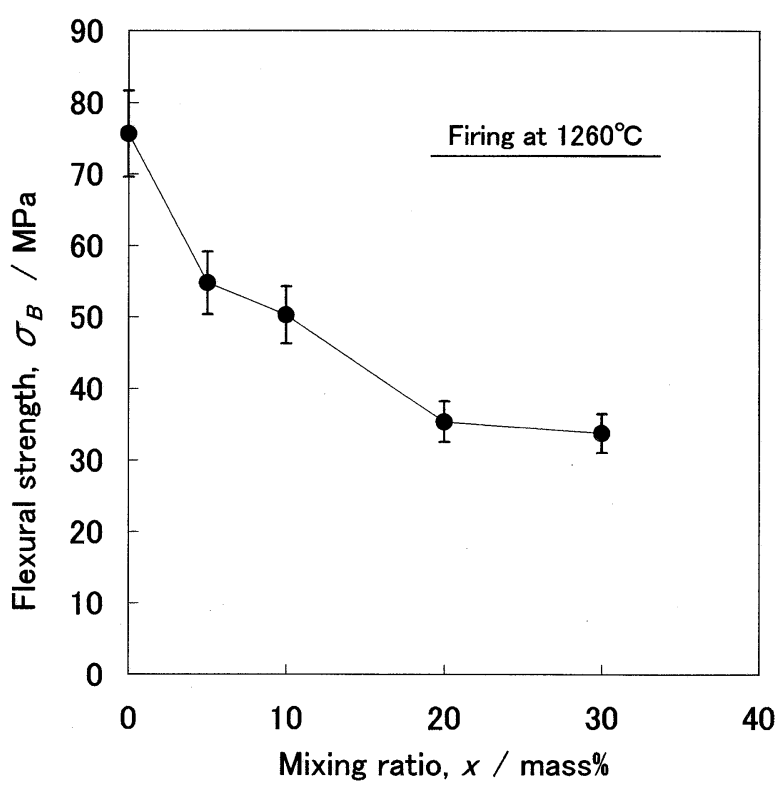

Fig. 5. Flexural strength, $\sigma_{\mathrm{B}}$ of the Shirasu-balloon mixed porcelains fired at $1260^{\circ} \mathrm{C}$ vs. the Mixing ratio, $x$.

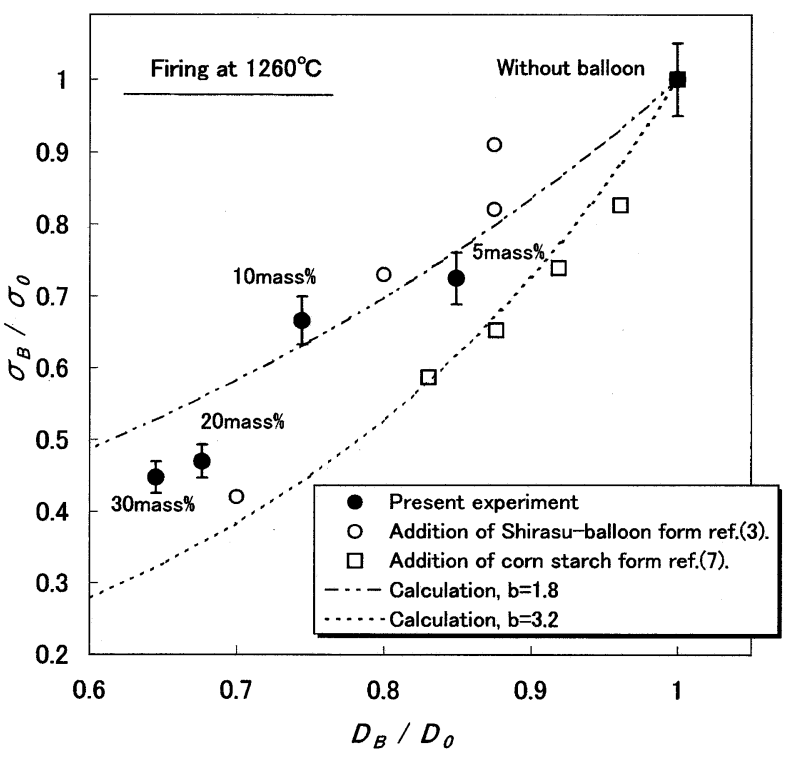

Fig. 6. The relationship between relative flexural strength, $\sigma_{\mathrm{B}} / \sigma_{0}$ and relative bulk density $D_{\mathrm{B}} / D_{0}$. The broken line shows the Eq (2).

た.ここで, 同様にシラスバルーンを混合した軽量陶磁器の 例3) とコーンスターチの混合により球状気孔を導入して軽量化 を試みた例7）（図 6 に併記）から，同様にその $b$ 值を求めると それぞれ $1.6,3.2$ 程度であり, 相対強度で見るかぎり, シラス バルーン混合による強度低下の抑制効果が認められる. バルー ンの混合率が 20 mass\%以上では強度低下の抑制は明らかでは ない.

シラスバルーンの混合率が 10 mass \%以下では, シラスバ ルーンが曲げ強度低下の抑制になんらかの効果をもたらしてい ることが考えられる.そこで，素地組織における内部応力を評 価するために，X線回折法により混合素地の石英粒子の面間 隔の変化を測定した. $1260^{\circ} \mathrm{C} て ゙$ 焼成した試料の焼成面におけ 


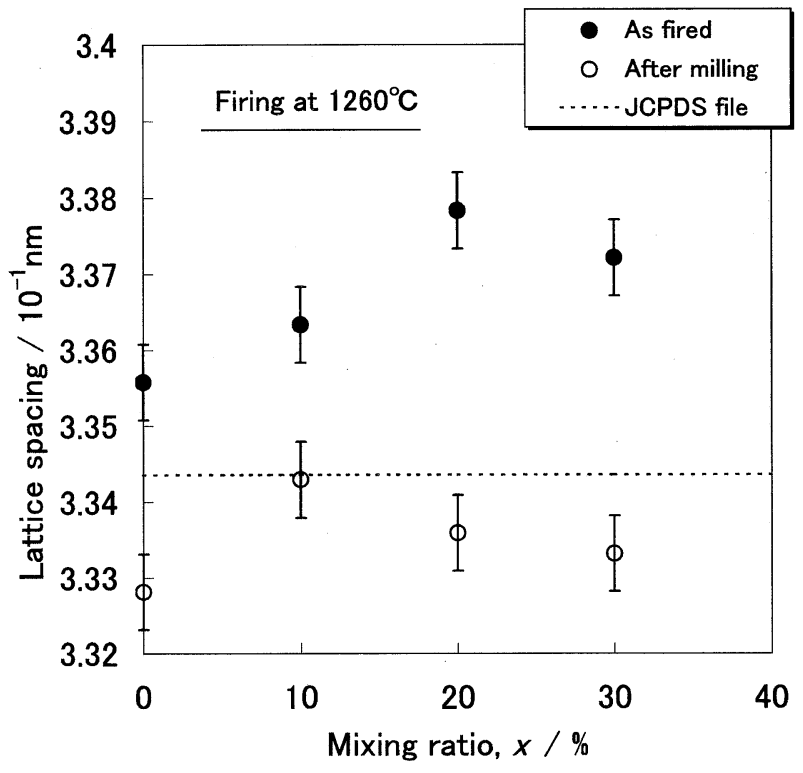

Fig. 7. Lattice spacing of quartz (101) of the Shirasu-balloon mixed porcelains fired at $1260^{\circ} \mathrm{C}$ vs. the Mixing ratio, $x$. The solid circles indicate the mixing porcelains, the open circles show the powder obtained by milling the mixing porcelains to release the internal stress.

る石英の（101）面の面間隔の変化を図 7 に示す．図 7 には, 内部応力を開放させる目的で, 上記焼成試料を粉砕したときの 結果も併せて示す．焼成体中の石英の面間隔は，シラスバルー ンの混合により増加したのに対して，粉砕後の試料では石英の 面間隔は一様に減少し応力が開放されることが分った．このこ とから，シラスバルーン混合による曲げ強度低下の抑制は，石 英粒子周辺の圧縮応力の存在によるものでめると考えられる. この原因として, シラスバルーン粒子から陶磁器素地への特定 成分の拡散などによるガラスマトリックスの熱膨張係数の変化 が考えられるが，今回はその測定を行っていないので明らかで はない. 一方，石英の面間隔は混合率 20 mass\%以上でも更に 増加しているが，曲げ強度低下は抑制されていない，これは， 素地組織における内部応力の効果よりも，シラスバルーン粒子 同士の接触による素地の脆弱化の影響を強く受けたためと推測 される。

\section{4. 結 論}

シラスバルーンを陶磁器素地に混合し, 閉気孔を高密度に形 成させることによる陶磁器の軽量化と強度低下の抑制について 検討し次の結論を得た。

(1) 陶磁器素地へのシラスバルーンの混合率が 10 mass \% までのとき, 素地のかざ密度の低下は, シラスバルーンの混合 率に対して加成的であった。これは陶磁器素地とシラスバルー ンの焼結温度や収縮率が同程度であった結果と考えられる.

（2）シラスバルーンを 20 mass\%以上混合すると，素地の かさ密度の低下はシラスバルーン混合率に対して加成的でなく なった.これはシラスバルーンの体積率が大きくなりバルーン 粒子同士が混合素地中で接触を起こしたために，バルーン粒子 が結合し，また外表面と連通することによって，シラスバルー ンの焼成収縮が大きくなり，閉気孔が失われた結果と考えられ る.

(3) 陶磁器素地へのシラスバルーンの混合率が 10 mass $\%$ 以下の場合, 曲げ強度の低下を抑制し得ることが分った．この 結果は, 混合素地中の石英粒子の面間隔の増加が観察されるこ とから，混合素地内部に圧縮応力が形成されたことによるもの と考えられる.

謝辞 本研究を遂行するにあたり，坏土を準備していただ いた愛媛県割業試験場・丹下理彦場長, 和氣誠研究員に感謝い たします。本研究は，平成10年度通産省工業技術院地域コンソー シアム研究開発制度の一環として, NEDOの委託を受けて行われ たものです.

\section{文献}

1) Hattori, S. and Yamanaka, S., "Takoshitsu Ceramics no Kaihatsu-Oyo," C. M. C (1985) pp. 219-29 [in Japanese].

2) Jinnai, K., Ceramics Japan, 36, 244-45 (2001) [in Japanese].

3) Sodeyama, K., Sakka, Y., Kamino, Y., Hamaishi, K., Kokusyo, T. and Seki, H., J. Ceram. Soc. Japan, 106, 333-38 (1998) [in Japanese].

4) Tai, W. and Kimura, K., J. Am. Ceram. Soc., 83, 1658-62 (2000).

5) Duke, D. A., Megles, Jr., J. E., Macdowell, J.F. and Bopp, H. F., J. Am. Ceram. Soc., 51, 98- 102 (1968).

6) Warshaw, S. I., Bull. Am. Ceram. Soc., 36, 28 (1957).

7) Kobayashi, Y. and Kato, E., J. Ceram. Soc. Japan, 106, 938-41 (1998) [in Japanese].

8) Soga, N., "Mechanical Properties of Ceramics," Ceram. Soc. Japan (1979) pp. 33-49 [in Japanese].

9) Kondo, R., “Takozairyo", Gihondo (1978) pp. 165-83 [in Japanese]. 